\title{
Las Cidalisas
}

¿Dónde están nuestras enamoradas?

Descansan en el sepulcro.

Son más felices en una morada más hermosa.

Muy cerca de los ángeles,

a la orilla de los cielos azules,

cantando las alabanzas

de la madre de Dios.

¡Oh, blanca prometida!

$¡ O h$, joven virgen en flor!

¡Amante abandonada

que el dolor marchitó...!

La profunda Eternidad

en sus ojos sonreía:

luminarias del mundo ya extinguidas,

en los cielos sean de nuevo encendidas. 